Article

\title{
Expression of Pro-Angiogenic Markers Is Enhanced by Blue Light in Human RPE Cells
}

\author{
Concetta Scimone ${ }^{1,2} \mathbb{D}$, Simona Alibrandi ${ }^{1,3}$, Sergio Zaccaria Scalinci ${ }^{4}$, \\ Edoardo Trovato Battagliola ${ }^{4}\left(\mathbb{D}\right.$, Rosalia $D^{\prime}$ Angelo ${ }^{1, *}\left(\mathbb{C}\right.$, Antonina Sidoti ${ }^{1}$ and Luigi Donato ${ }^{1,2}$ \\ 1 Department of Biomedical, Dental, Morphological and Functional Imaging Sciences, University of Messina, \\ 98125 Messina, Italy; cscimone@unime.it (C.S.); salibrandi@unime.it (S.A.); asidoti@unime.it (A.S.); \\ ldonato@unime.it (L.D.) \\ 2 Department of Biomolecular Strategies, Genetics and Avant-Garde Therapies, I.E.ME.S.T., \\ 90139 Palermo, Italy \\ 3 Department of Chemical, Biological, Pharmaceutical and Environmental Sciences, University of Messina, \\ 98166 Messina, Italy \\ 4 DIMEC (Department of Medical and Surgical Sciences), University of Bologna, 40121 Bologna, Italy; \\ sergio.scalinci@unibo.it (S.Z.S.); etbattagliola@gmail.com (E.T.B.) \\ * Correspondence: rdangelo@unime.it; Tel.: +39-0902-2133-72
}

Received: 16 October 2020; Accepted: 18 November 2020; Published: 20 November 2020

\begin{abstract}
Inherited retinal dystrophies are characterized by photoreceptor death. Oxidative stress usually occurs, increasing vision loss, and oxidative damage is often reported in retinitis pigmentosa (RP). More than 300 genes have been reported as RP causing. In contrast, choroidal neovascularization $(\mathrm{CNV})$ only occasionally develops in the late stages of RP. We herein study the regulation of $\mathrm{RP}$ causative genes that are likely linked to $\mathrm{CNV}$ onset under oxidative conditions. We studied how the endogenous adduct $N$-retinylidene- $N$-retinylethanolamine (A2E) affects the expression of angiogenic markers in human retinal pigment epithelium (H-RPE) cells and a possible correlation with RP-causing genes. H-RPE cells were exposed to A2E and blue light for 3 and 6 h. By transcriptome analysis, genes differentially expressed between A2E-treated cells and untreated ones were detected. The quantification of differential gene expression was performed by the Limma $R$ package. Enrichment pathway analysis by the FunRich tool and gene prioritization by ToppGene allowed us to identify dysregulated genes involved in angiogenesis and linked to RP development. Two RP causative genes, $A H R$ and ROM1, can be associated with an increased risk of CNV development. Genetic analysis of RP patients affected by CNV will confirm this hypothesis.
\end{abstract}

Keywords: oxidative stress; retinitis pigmentosa; angiogenesis; choroidal neovascularization; biomarkers

\section{Introduction}

The normal retina is organized in several tightly interconnected layers forming a unique structural and functional complex. The retinal pigment epithelium (RPE) is the basal layer and separates photoreceptors from the choriocapillaris vascular bed. RPE is a monolayer of polarized neural-crista-derived pigmented epithelial cells. On the apical side, it interacts with the outer segments of the photoreceptors, while on the basolateral surface it makes contact with Bruch's membrane and choriocapillaris [1]. Although RPE provides nutrients for photoreceptors, it also takes part in the phototransduction process, being the site of visual pigment turn-over [2]. Moreover, RPE mediates metabolite transport between choriocapillaris and photoreceptors. Together with endothelial cells, it forms the blood-retinal barrier (BRB), a highly selective structure that regulates molecule passage from blood to retina [3]. By pumping fluid out from the subretinal space, RPE contributes to 
maintaining the negative hydrostatic pressure required for adhesion between RPE and photoreceptors. $\mathrm{Cl}^{-}$ions enter RPE cells at the apical membrane by $\mathrm{Na}^{+} / \mathrm{K}^{+}$ATPase and exit the basolateral one by $\mathrm{Cl}^{-}$channels. Water transport from subretinal space to choriocapillaris is associated to this ion flow [4-6]. RPE also secretes several growth factors involved in the regulation of vascular endothelium homeostasis. Among these, the pigment epithelium-derived factor (PEDF, encoded by the SERPINF1 gene) acts as an antiangiogenic molecule on choriocapillaris and exerts a neuroprotective function against hypoxia-induced apoptosis [7]. Surprisingly, somatostatin, erythropoietin (EPO) and ApoA1 are also secreted by RPE cells. In the retina, somatostatin regulates $\mathrm{Ca}^{2+}$ signaling, glutamate release, ions and water transport, and nitric oxide function, and acts as an antiangiogenic factor on endothelial cells [8]. EPO protects retinal cells from light-induced damage and oxidative stress by inhibiting caspase and preventing apoptosis, and up-regulates the expression of pro-angiogenic factors, such as vascular endothelial growth factor (VEGF) [9]. Other vasoactive molecules produced by RPE include thrombospondin 1, which is highly represented in Bruch's membrane [10]. Retinal angiogenesis dysfunction can arise following oxidative stress stimuli and inflammatory cascade activation often resulting in photoreceptor degeneration [11,12]. Visual cycle reactions endogenously generate reactive oxygen species (ROS) together with lipofuscin that accumulates within RPE cells. The bis-retinoid $N$-retinylidene- $N$-retinylethanolamine (A2E) is one of the major components of lipofuscin and is synthetized from all-trans-retinal and phosphatidylethanolamine. Following light exposure, A2E contributes to increase ROS levels, becoming toxic to RPE. Light exposure also induces retinal neovascularization mediated by the upregulation of VEGF. Neo-vessels probably create anastomosis with the choroid leading to retinal atrophy due to photoreceptor degeneration [13]. Although vessel formation is enhanced in certain eye diseases, such as age-related macular degeneration (AMD) or diabetic retinopathy [14], loss of choriocapillaris is observed in the late stages of retinitis pigmentosa (RP) [15]. RP comprises a wide spectrum of retinal dystrophies characterized by progressive peripheral vision loss and night blindness due to rod degeneration and impaired RPE. Cone death and loss of central vision occur during disease progression as a consequence of both the cytotoxic activity of the degenerated rods and reduced rod-derived cone viability factors. In addition, retinal vascular attenuation and choriocapillaris atrophy occur later, following photoreceptor degeneration due to reduced metabolic demand during retinal atrophy [16]. In this context, increased levels of plasma endothelin-1 (ET-1) have been found in RP patients [17]. ET-1 is produced in RPE and its expression is stimulated by thrombin treatment [18]. Reduced oxygen demand in RP retina directly determines the increase in extracellular oxygen concentration, enhancing RPE migration [19,20]. However, RP patients occasionally develop choroidal neovascularization (CNV), an abnormal intravasation of choroidal vasculature into the RPE or subretinal tissue [21]. To date, more than 300 genes have been identified as causative of retinal dystrophies. However, molecular mechanisms leading to CNV onset have not yet been elucidated. It is well known that it may be resolved by intravitreal injection of bevacizumab, a monoclonal antibody that blocks VEGF activity [22], suggesting that CNV can arise due to an imbalance between pro-angiogenic and anti-angiogenic factors. However, there is little literature available on RP causative genes and their role in CNV development. The aim of the present study is to clarify if, following $\mathrm{A} 2 \mathrm{E}$ and blue light exposure, CNV can be documented in specific RPE subtypes linked to specific causative gene(s). In other words, the main idea is to provide preliminary findings on the evidence that not all RP causative genes can predispose to CNV onset under stressed conditions from A2E. Therefore, we studied the expression of angiogenetic markers in RPE cells treated with A2E and prioritized dysregulated genes with those that cause RP. Although RP is an inherited disease, an increase in ROS levels due to rod death seems to play a crucial role in disease progression, promoting cone degeneration and RPE dysfunction [23]. 


\section{Materials and Methods}

\subsection{Human Retinal Pigment Epithelial Cell Culture Maintenance}

Human primary RPE-derived cells (H-RPE-Human Retinal Pigment Epithelial Cells, 2nd passage, Clonetics $^{\mathrm{TM}}$, Lonza, Walkersville, MD, USA) were cultured in T-75 flasks with RtEGM ${ }^{\mathrm{TM}}$ Retinal Pigment Epithelial Cell Growth Medium BulletKit ${ }^{\circledR}$ (Clonetics ${ }^{\mathrm{TM}}$, Lonza, Walkersville, MD, USA), with added $2 \% v / v$ fetal bovine serum (FBS), $1 \%$ penicillin/streptomycin. Maintenance conditions were set at $37^{\circ} \mathrm{C}$ with $5 \% \mathrm{CO}_{2}$. Before treatment, $4 \times 10^{4} \mathrm{H}$-RPE cells/well were transferred into 96-well plates (3rd passage). Three wells were considered for each condition. A2E was added to cells, after they reached confluence. The final A2E concentration was $20 \mu \mathrm{M}$. H-RPE cells were then transferred to phosphate-buffered saline (PBS) supplemented with calcium, magnesium and glucose (PBS-CMG). Exposure to a tungsten-halogen source $\left(470 \pm 20 \mathrm{~nm} ; 0.4 \mathrm{~mW} / \mathrm{mm}^{2}\right)$ allowed for A2E activation, mimicking cytotoxicity induced by blue light. The exposure time was $30 \mathrm{~min}$. Then, cells were incubated at $37^{\circ} \mathrm{C}$ up to three different time points, 3, 6 and $9 \mathrm{~h}$. To compare gene expression, a negative control was obtained by irradiating H-RPE cells with blue light but not treating them with A2E (0 h_untreated). This choice was driven by the evidence that, without A2E, blue light is not sufficient to trigger oxidative damage, as is required for A2E activation.

\subsection{Methylthiazolyldiphenyl-Tetrazolium Bromide Assay to Test Cell Viability}

The methylthiazolyldiphenyl-tetrazolium bromide (MTT) assay allows one to assess cell viability by measurement of the mitochondrial-dependent reduction of MTT (Sigma-Aldrich, St. Louis, MO, USA) to formazan insoluble crystals. Following A2E treatment, $10 \mu \mathrm{L}$ of $5 \mathrm{mg} / \mathrm{mL}$ of MTT was diluted in PBS and added to the cell medium. H-RPE cells were incubated at $37^{\circ} \mathrm{C}$ for $2 \mathrm{~h}$ before adding $100 \mu \mathrm{L}$ $10 \%$ SDS (sodium dodecyl sulfate) in $0.01 \mathrm{~mol} / \mathrm{L} \mathrm{HCl}$. Cultures were incubated for $16 \mathrm{~h}$ and then read in a Dynatech microplate reader set to $570 \mathrm{~nm}$ absorbance. Untreated H-RPE cells were exposed to blue light, but A2E-untreated H-RPE cells were considered a negative control. The experiment was repeated three times.

\subsection{RNA Extraction and Whole Transcriptome Analysis}

TRIzol $^{\mathrm{TM}}$ reagent (Invitrogen ${ }^{\mathrm{TM}}$, ThermoFisher Scientific, Waltham, MA, USA) was used to purify total RNA from H-RPE cells. RNA extraction yield was assessed at the Qubit 2.0 fluorimeter by the Qubit $^{\circledR}$ RNA assay kit (Invitrogen ${ }^{\mathrm{TM}}$, ThermoFisher Scientific, Waltham, MA, USA). Following A2E treatment, two different time points were considered at 3 and $6 \mathrm{~h}$, respectively. A2E-untreated H-RPE cells, exposed to blue light, were used as a negative control (time point: $0 \mathrm{~h}$ ). Each time point was processed three times, obtaining nine libraries in total. A total of $1 \mu \mathrm{g}$ of total RNA was used to generate paired-end libraries by the TruSeq Stranded Total RNA Sample Prep Kit with Ribo-Zero H/M/R (Illumina, San Diego, CA, USA). Following amplification, libraries were run on a HiSeq 2500 Sequencer (Illumina, San Diego, CA, USA), using the HiSeq SBS Kit v4 (Illumina, San Diego, CA, USA).

\subsection{FASTQ Data Quality Control and Read Mapping}

The quality check of FASTQ data generated by sequencing run was assessed by the FastQC (v.0.11.9) (https://www.bioinformatics.babraham.ac.uk/projects/fastqc/) and the QualiMap (v.2.2.1) tools [24]. Reads having a Phred quality score $<30$ were removed by the Trimmomatic (v.0.39) tool [25]. Filtered reads were mapped to the GRCh38 Human Reference Genome and the Ensembl RNA database v.99, by the Qiagen CLC Genomics Workbench v.20.0 software package (Qiagen, Hilden, Germany) (https://digitalinsights.qiagen.com/products-overview/analysis-and-visualization/ qiagen-clc-genomics-workbench/). 


\subsection{Gene Expression Quantification, Differential Gene Expression (DGE) and Statistical Analysis}

Aligned reads were quantified by the mapping-dependent expectation-maximization (EM) algorithm [26]. Differential gene expression (DGE) analysis was performed by the Limma R package [27]. The three different conditions were compared as described: (i) 0 h_untreated vs. 3 h_treated, (ii) 0 h_untreated vs. 6 h_treated, (iii) 3 h_treated vs. 6 h_treated. DGE was expressed as $\log _{2}$ fold change $\left(\log _{2} \mathrm{FC}\right)$ of the gene abundance.

\subsection{Functional Gene Annotation, Enrichment Analysis and Gene Prioritization}

Differentially expressed genes (DEGs) were annotated based on the InterPro [28], Reactome [29], Human Protein Atlas [30], UniProt [31], IntAct [32], Ensembl [33] and HGNC [34] databases. Functional enrichment and gene clustering analysis were performed by the FunRich: Functional Enrichment analysis tool, according to the biological pathways [35]. A full list of dysregulated genes was inputted. Only pathways showing the Bonferroni-adjusted $p$-value $<0.05$ were considered.

To identify RP causative genes that might enhance angiogenesis, prioritization analysis with the ToppGene tool [36] was performed. In detail, genes related to retinal vascular development, dysregulated in A2E-treated H-RPE cells (VEGFA, PDGFB, CCN1, LRP5, FZD4), were used as the "training gene set". As the "Test gene set", all those reported in the RetNet database (https://sph.uth. edu/retnet/home.htm) were inputted. Considered annotation terms included: "GO: Biological Process", "Human phenotype", "Mouse phenotype", "Pathway", "PubMed" and "Disease". Only results showing the Bonferroni-adjusted $p$-value $<0.05$ were considered significant.

\subsection{Quantitative RT-PCR Data Validation}

To validate observed FC values from RNA-Sequencing, quantitative real-time polymerase chain reaction (qRT-PCR) was performed. Six genes were selected and quantified at both time points (3 h_vs._0 h, 6 h_vs._0 h) (Table 1). Retrotranscription was carried out by the High-Capacity cDNA Reverse Transcription Kit with RNase Inhibitor (Applied Biosystems ${ }^{\mathrm{TM}}$, Fisher Scientific, Loughborough, Leicestershire, UK) using $1 \mu \mathrm{g}$ total RNA for $20 \mu \mathrm{L}$ of reaction volume. Within the reaction mix, $50 \mathrm{ng}$ of cDNA, $200 \mathrm{nM}$ of each specific primer and $10 \mu \mathrm{L}$ SYBR $^{\mathrm{TM}}$ Select Master Mix (Applied Biosystems ${ }^{\mathrm{TM}}$, Fisher Scientific, Loughborough, Leicestershire, UK) were added. Each reaction was repeated thrice and gene expression was measured by an Applied Biosystems ${ }^{\circledR} 7500$ Fast Real-Time PCR System (Applied Biosystems, Foster City, CA, USA) by calculating the average threshold cycle (Ct) from the values obtained for each reaction. Relative gene expression was quantified using the $2^{-\Delta \Delta C t}$ method. The expression level of $\beta$-actin was used for data normalization.

\subsection{Statistical Analysis}

In MTT assay, the cell viability of H-RPE cells was expressed as average percentage values from three replicates for each condition, and the standard deviation was calculated.

RNA-seq runs were also replicated three times. Differential gene expression was reported as $\log _{2} \mathrm{FC}$, and statistical significance was assessed by the multiple t-test, considering the Bonferroni-adjusted $p$-value $<0.05$ as significance threshold.

Quantitative RT-PCR reactions were repeated three times and the average threshold cycle (Ct) by the values obtained for each reaction was calculated. Expression values are reported as mean of $\log _{2}$ FC. Correlation analysis between qRT-PCR and RNA-Seq gene expression values was obtained by linear regression with IBM SPSS 26.0 software (https://www.ibm.com/analytics/us/en/technology/spss/). 
Table 1. Transcripts selected for RNA-seq data validation by quantitative real-time polymerase chain reaction (qRT-PCR). Regarding the data discussed in the text, 3 down-expressed and 3 up-regulated coding genes were chosen for data validation. For each gene, the HUGO (Human Genome Organization) Gene Nomenclature Committee (HGNC) name, the Ensembl-specific transcript ID, the $\log _{2}$ fold change detected by RNAseq at both 3 and $6 \mathrm{~h}$ after $N$-retinylidene- $N$-retinylethanolamine (A2E) treatment, the primer pair and the specific length of the amplicon are reported. FC: fold change; bp: base-pairs.

\begin{tabular}{|c|c|c|c|c|c|}
\hline $\begin{array}{l}\text { HGNC Gene } \\
\text { Name (ID) }\end{array}$ & $\begin{array}{c}\text { Ensembl } \\
\text { Transcript ID }\end{array}$ & $\begin{array}{c}3 \text { h_vs._0 h RNAseq } \\
\text { log2 FC }\end{array}$ & $\begin{array}{c}6 \text { h_vs._0 h RNAseq } \\
\log 2 \text { FC }\end{array}$ & Primer Pair & $\begin{array}{l}\text { Fragment } \\
\text { Length (bp) }\end{array}$ \\
\hline OCLN (8104) & ENST00000355237.2 & -0.873423348 & -1.391662424 & $\begin{array}{l}\text { ACTTCGCCTGTGGATGACTT } \\
\text { GACCTTCCTGCTCTTCCCTT }\end{array}$ & 101 \\
\hline $\begin{array}{l}\text { RICTOR } \\
(28611)\end{array}$ & ENST00000357387.8 & -0.940830609 & -0.705087984 & $\begin{array}{l}\text { GCTCTCTGAAGAACCTCCGA } \\
\text { CCTGCAATCTGGCCACATTT }\end{array}$ & 126 \\
\hline TJP1 (11827) & ENST00000356107.10 & -0.694212076 & -1.059176648 & $\begin{array}{l}\text { TCTTCGCAGCTCCAAGAGAA } \\
\text { AGGCCTCAGAAATCCAGCTT }\end{array}$ & 121 \\
\hline FZD4 (4042) & ENST00000531380.2 & 0.37699785 & 0.532274651 & $\begin{array}{l}\text { GGTTTGGTGGCCTTGTTCAA } \\
\text { ATCACACACGTTGCAGGAAC }\end{array}$ & 131 \\
\hline KIFC3 (6326) & ENST00000445690.7 & 0.995878391 & 1.422298598 & $\begin{array}{l}\text { GACCCTCACCAACGACTACA } \\
\text { TTGCTGTTGACCTCCTCGAT }\end{array}$ & 123 \\
\hline VEGFA (12628) & ENST00000372055.8 & 0.137384927 & 1.016674127 & $\begin{array}{l}\text { CTGTCTTGGGTGCATTGGAG } \\
\text { TGATGATTCTGCCCTCCTCC }\end{array}$ & 101 \\
\hline
\end{tabular}

\section{Results}

\subsection{A2E Affects H-RPE Cell Viability}

The cytotoxic effect of A2E and light exposure were tested in H-RPE cells. Induced cytotoxicity increased in a time-dependent manner, as shown by the cell viability trend seen in Figure 1. Cell viability was drastically decreased after $9 \mathrm{~h}$ of A2E and thus this time point was not considered for subsequent analysis.

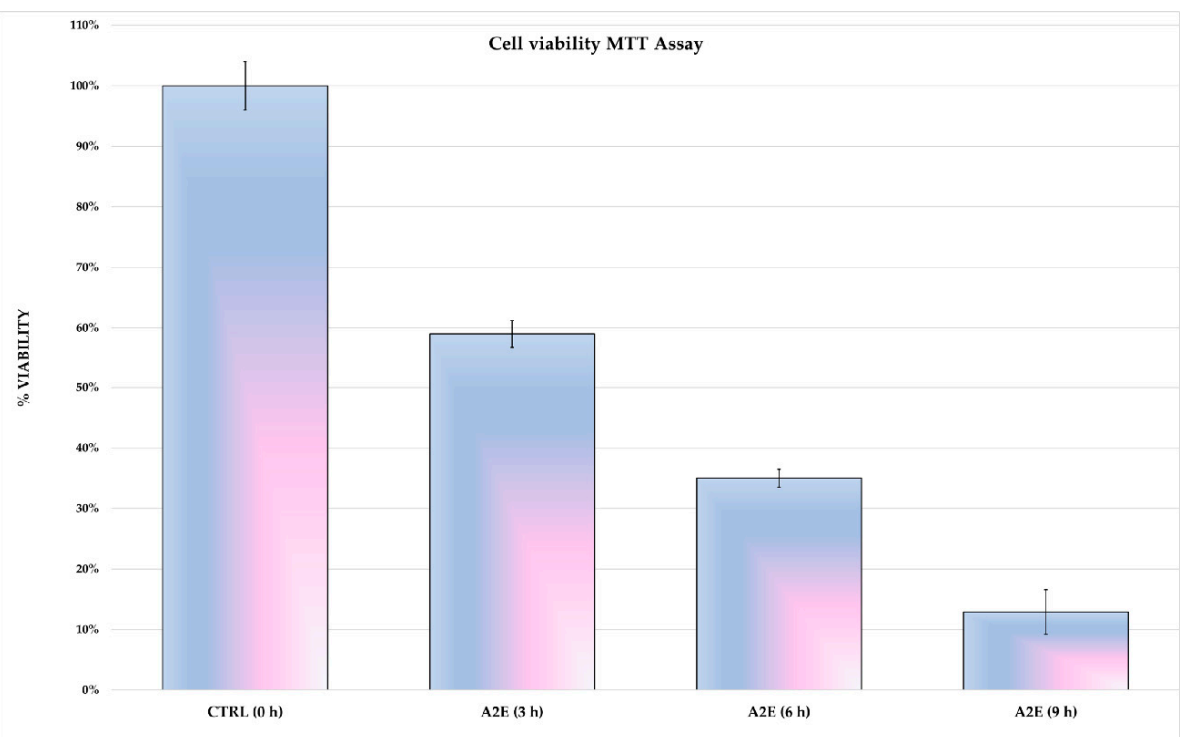

Figure 1. Methylthiazolyldiphenyl-tetrazolium bromide (MTT)-viability assay results. $N$-retinylidene$\mathrm{N}$-retinylethanolamine (A2E) had a cytotoxic effect on human retinal pigment epithelium (H-RPE) cells in a time-dependent manner. The viability of untreated $(0 \mathrm{~h}) \mathrm{H}-\mathrm{RPE}$ cells and 3, 6 and $9 \mathrm{~h}$ A2E-exposed $\mathrm{H}-\mathrm{RPE}$ cells is expressed as a percentage, as the mean $\pm \mathrm{SD}(n=3)$. Statistical significance was assessed by multiple t-tests ( $p$-values $<0.05$ ). Due to markedly decreased cell viability at $9 \mathrm{~h}$ with A2E, this time point was excluded in further analysis. 


\subsection{Transcriptome Analysis and Differential Gene Expression}

Bulk RNA sequencing generated about 100,000,000 reads showing a mean mapping Phred quality score $\geq 30$. Unique mapped reads amounted to $67.8 \%$. DEGs were divided according to the comparison between the different time points. In detail, 3878 and 4526 genes were differentially expressed between treated and untreated H-RPE cells, respectively, 3 and $6 \mathrm{~h}$ after A2E and light exposure. From a comparison between the two time points after treatment $(6 \mathrm{~h} \mathrm{vs.} 3 \mathrm{~h}), 956$ genes showed significative change in expression level (Figure 2) (Table S1).

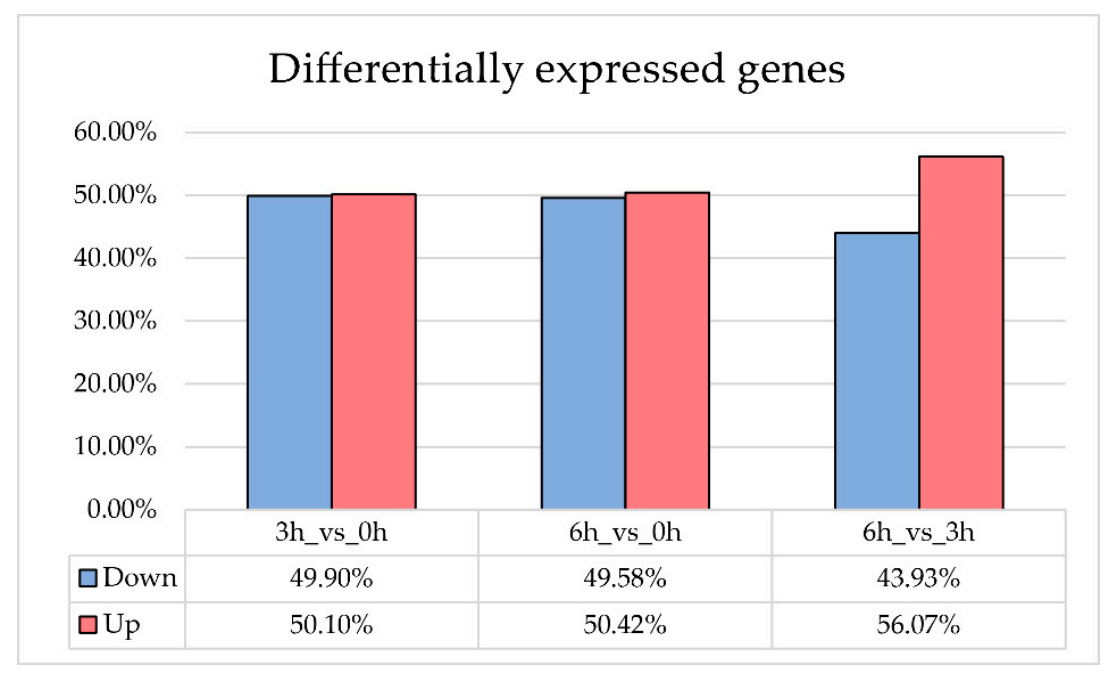

Figure 2. Differentially Expressed Genes (DEGs) in A2E-treated RPE cells. The histogram shows DEGs detected in RPE cells treated with A2E when compared to untreated cultures. Values are expressed in percentage. For each time point considered, blue bars indicate the down-expressed genes, while red ones refer to up-regulated genes. Both A2E-treated cells and control H-RPE cells were exposed to a blue light period.

\subsection{Functional Pathway Analysis}

Functional enrichment analysis clustered dysregulated genes in 1309 and 1349 pathways at 3 and $6 \mathrm{~h}$ after A2E treatment, respectively (Tables S2-S4). Regarding the first time point ( $3 \mathrm{~h}$ _vs._0 h), 141 pathways showed statistical significance and, of these, 19 were related to angiogenesis. Six hours after treatment (6 h_vs._0 h), the number of enriched pathways increased to 1349 . However, of these, only 18 regarded the regulation of vessel morphogenesis (Tables S2-S4). Moreover, the comparison of expression values observed 6 and $3 \mathrm{~h}\left(6 \mathrm{~h} \_v s . \_3 \mathrm{~h}\right)$ after A2E treatment allowed us to identify how the dysregulation of several pathways occurred in a time-dependent manner (Table 2). These include pathways related to the maintenance of endothelial cell property, such as cytoskeleton regulation and cell junction stabilization. Nevertheless, A2E treatment resulted in extra-cellular matrix (ECM) impairment by affecting $\beta$-integrin and proteoglycan signaling. 
Table 2. Enrichment pathway analysis results. The table shows results obtained by the FunRich tool. Only pathways related to angiogenesis are reported. For each time point, the percentage of enriched genes, the fold enrichment and the Bonferroni-adjusted $p$-value are reported. Not significant: fold enrichment $p$-value $\geq 0.05$.

\begin{tabular}{|c|c|c|c|c|c|c|c|c|c|}
\hline \multirow[b]{2}{*}{ Pathway } & \multicolumn{3}{|c|}{$3 \mathrm{~h} \_$vs._0 h } & \multicolumn{3}{|c|}{$6 \mathrm{~h} \_$vs._0 h } & \multicolumn{3}{|c|}{$6 \mathrm{~h} \_v s . \_3 \mathrm{~h}$} \\
\hline & $\begin{array}{l}\text { \% Enriched } \\
\text { Genes }\end{array}$ & $\begin{array}{c}\text { Fold } \\
\text { Enrichment }\end{array}$ & $\begin{array}{c}p \text {-Value } \\
\text { (Bonferroni-Adjusted) }\end{array}$ & $\begin{array}{l}\text { \% Enriched } \\
\text { Genes }\end{array}$ & $\begin{array}{c}\text { Fold } \\
\text { Enrichment }\end{array}$ & $\begin{array}{c}p \text {-Value } \\
\text { (Bonferroni-Adjusted) }\end{array}$ & $\begin{array}{l}\text { \% Enriched } \\
\text { Genes }\end{array}$ & $\begin{array}{c}\text { Fold } \\
\text { Enrichment }\end{array}$ & $\begin{array}{c}p \text {-Value } \\
\text { (Bonferroni-Adjusted) }\end{array}$ \\
\hline $\begin{array}{l}\text { Beta1 integrin } \\
\text { cell surface } \\
\text { interactions }\end{array}$ & 25.4 & 1.1854 & 0.0146 & 26.9 & 1.2561 & $1.0167 \times 10^{-7}$ & 34.1 & 1.5901 & $1.441 \times 10^{-7}$ \\
\hline $\begin{array}{l}\text { EGFR-dependent } \\
\text { Endothelin } \\
\text { signalling events }\end{array}$ & 24.2 & 1.1825 & 0.03440 & 25.9 & 1.2690 & $4.5939 \times 10^{-8}$ & 33.6 & 1.645 & $1.3314 \times 10^{-8}$ \\
\hline Endothelins & \multicolumn{3}{|c|}{ Not significant } & 26.1 & 1.26 & $1.3783 \times 10^{-7}$ & 33.6 & 1.6222 & $4.1668 \times 10^{-8}$ \\
\hline $\begin{array}{l}\text { HIF-1-alpha } \\
\text { transcription } \\
\text { factor network }\end{array}$ & \multicolumn{3}{|c|}{ Not significant } & \multicolumn{3}{|c|}{ Not significant } & 5.1 & 4.8831 & $8.0756 \times 10^{-8}$ \\
\hline IGF1 pathway & 24.2 & 1.1838 & 0.0297 & 25.9 & 1.2670 & $6.044 \times 10^{-8}$ & 33.6 & 1.6424 & $1.5141 \times 10^{-8}$ \\
\hline $\begin{array}{c}\text { LKB1 signalling } \\
\text { events }\end{array}$ & 24.8 & 1.1964 & 0.0070 & 26.5 & 1.2809 & $4.0980 \times 10^{-9}$ & 33.6 & 1.6210 & $4.4347 \times 10^{-8}$ \\
\hline $\begin{array}{c}\mathrm{N} \text {-cadherin } \\
\text { signalling events }\end{array}$ & \multicolumn{3}{|c|}{ Not significant } & \multicolumn{3}{|c|}{ Not significant } & 8.2 & 2.0655 & 0.0252 \\
\hline $\begin{array}{l}\text { Nectin adhesion } \\
\text { pathway }\end{array}$ & 24.2 & 1.1801 & 0.0409 & 26.0 & 1.2659 & $6.6551 \times 10^{-8}$ & 34.1 & 1.6590 & $4.2976 \times 10^{-9}$ \\
\hline $\begin{array}{l}\text { PDGF receptor } \\
\text { signalling } \\
\text { network }\end{array}$ & 24.3 & 1.1851 & 0.0257 & 26.06 & 1.2707 & $3.2165 \times 10^{-8}$ & 33.8 & 1.6507 & $8.0949 \times 10^{-9}$ \\
\hline $\begin{array}{l}\text { Posttranslational } \\
\text { regulation of } \\
\text { adherens junction } \\
\text { stability and } \\
\text { disassembly }\end{array}$ & \multicolumn{3}{|c|}{ Not significant } & \multicolumn{3}{|c|}{ Not significant } & 7.8 & 2.1230 & 0.0235 \\
\hline $\begin{array}{c}\text { Proteoglycan } \\
\text { syndecan-mediated } \\
\text { signalling events }\end{array}$ & 25.3 & 1.1846 & 0.0167 & 27.1 & 1.2724 & $7.3776 \times 10^{-9}$ & 35.0 & 1.6389 & $5.2725 \times 10^{-9}$ \\
\hline $\begin{array}{l}\text { RAC1 signalling } \\
\text { pathway }\end{array}$ & \multicolumn{3}{|c|}{ Not significant } & \multicolumn{3}{|c|}{ Not significant } & 7.3 & 2.2556 & 0.0113 \\
\hline
\end{tabular}


Table 2. Cont.

\begin{tabular}{|c|c|c|c|c|c|c|c|c|c|}
\hline \multirow[b]{2}{*}{ Pathway } & \multicolumn{3}{|c|}{3 h_vs._0 h } & \multicolumn{3}{|c|}{6 h_vs._0 h } & \multicolumn{3}{|c|}{6 h_vs._3 h } \\
\hline & $\begin{array}{l}\text { \% Enriched } \\
\text { Genes }\end{array}$ & $\begin{array}{c}\text { Fold } \\
\text { Enrichment }\end{array}$ & $\begin{array}{c}p \text {-Value } \\
\text { (Bonferroni-Adjusted) }\end{array}$ & $\begin{array}{l}\text { \% Enriched } \\
\text { Genes }\end{array}$ & $\begin{array}{c}\text { Fold } \\
\text { Enrichment }\end{array}$ & $\begin{array}{c}p \text {-Value } \\
\text { (Bonferroni-Adjusted) }\end{array}$ & $\begin{array}{l}\text { \% Enriched } \\
\text { Genes }\end{array}$ & $\begin{array}{c}\text { Fold } \\
\text { Enrichment }\end{array}$ & $\begin{array}{c}p \text {-Value } \\
\text { (Bonferroni-Adjusted) }\end{array}$ \\
\hline $\begin{array}{l}\text { Regulation of } \\
\text { CDC42 activity }\end{array}$ & \multicolumn{3}{|c|}{ Not significant } & 15.2 & 1.2478 & 0.0083 & 22.7 & 1.8607 & $1.1663 \times 10^{-7}$ \\
\hline $\begin{array}{c}\text { RhoA signalling } \\
\text { pathway }\end{array}$ & \multicolumn{3}{|c|}{ Not significant } & \multicolumn{3}{|c|}{ Not significant } & 7.3 & 2.2556 & 0.0113 \\
\hline $\begin{array}{l}\text { Signalling events } \\
\text { mediated by focal } \\
\text { adhesion kinase }\end{array}$ & 24.2 & 1.1834 & 0.0317 & 25.9 & 1.27 & $4.0022 \times 10^{-8}$ & 33.6 & 1.6462 & $1.2483 \times 10^{-8}$ \\
\hline $\begin{array}{l}\text { Signalling events } \\
\text { mediated by } \\
\text { Hepatocyte } \\
\text { Growth Factor } \\
\text { Receptor (c-Met) }\end{array}$ & 24.3 & 1.1851 & 0.0257 & 26.0 & 1.2679 & $5.0634 \times 10^{-8}$ & 33.6 & 1.6398 & $1.7211 \times 10^{-8}$ \\
\hline $\begin{array}{l}\text { Signalling events } \\
\text { mediated by } \\
\text { VEGFR1 and } \\
\text { VEGFR2 }\end{array}$ & 24.7 & 1.1855 & 0.0240 & 26.1 & 1.2705 & $3.0898 \times 10^{-8}$ & 33.8 & 1.6469 & $9.8334 \times 10^{-9}$ \\
\hline $\begin{array}{l}\text { Stabilization and } \\
\text { expansion of the } \\
\text { E-cadherin } \\
\text { adherens junction }\end{array}$ & \multicolumn{3}{|c|}{ Not significant } & \multicolumn{3}{|c|}{ Not significant } & 9.3 & 2.1399 & 0.0025 \\
\hline $\begin{array}{l}\text { Syndecan-1-mediated } \\
\text { signalling events }\end{array}$ & 24.5 & 1.1881 & 0.0178 & 26.2 & 1.2721 & $2.1586 \times 10^{-8}$ & 33.6 & 1.6310 & $2.6854 \times 10^{-8}$ \\
\hline $\begin{array}{c}\text { VEGF and } \\
\text { VEGFR signalling } \\
\text { network }\end{array}$ & 24.4 & 1.1782 & 0.0455 & 26.2 & 1.2655 & $5.8984 \times 10^{-8}$ & 33.8 & 1.6368 & $1.6437 \times 10^{-8}$ \\
\hline
\end{tabular}




\subsection{A2E Treatment CAUSES Loss of Retinal Blood Barrier Properties}

Enriched pathways related to the vessel development clustered in total $423(3 \mathrm{~h})$ and $522(6 \mathrm{~h})$ DEGs in A2E-treated H-RPE cells, when compared to untreated ones. Moreover, 175 genes were further dysregulated between 3 and $6 \mathrm{~h}$, after A2E exposure. Of these, 24 were uniquely detected in this time lapse (Figure 3; Table S5).

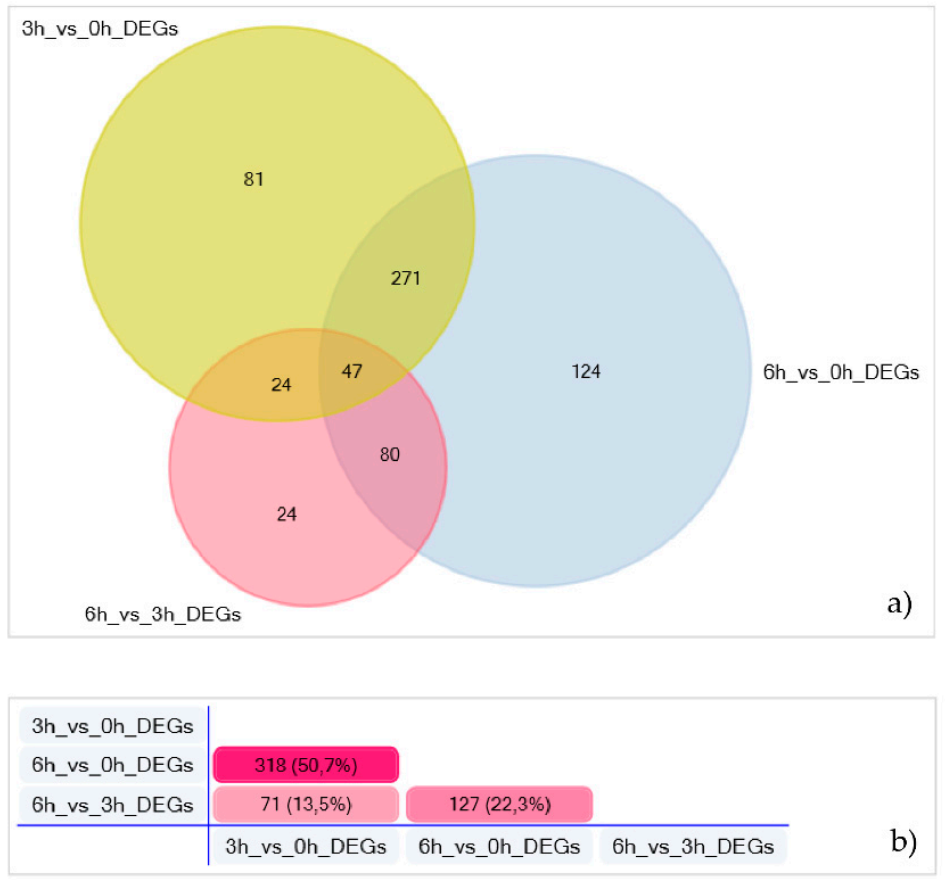

Figure 3. Angiogenesis-related genes dysregulated in A2E-treated H-RPE cells. (a) The Venn diagram reports the number of angiogenesis-related DEGs, for each time point (intersections).

(b) Pair-comparison highlighting the percentage of DEGs between time-point pairs.

Genes encoding for proteins involved in the maintenance of tight junction integrity (TJP1, OCLN, ROCK1) were slightly down-regulated at the first time point $\left(3 \mathrm{~h}, \log _{2} \mathrm{FC}>-1\right)$, in contrast to those encoded for proteins involved in adherens zonula formation (CAMSAP3, KIFC3) that were up-regulated, suggesting that A2E can impair BRB properties, increasing its permeability. Together with the cell-cell junction, light damage also affected cytoskeleton organization due to the down-expression of genes such as RICTOR, which contributes to the maintenance of actin cytoskeleton polarity, JMY, which acts as a de novo actin filament nucleation, and RHOA, which regulates endothelial tube lumen extension. Moreover, ARAP1 was up-regulated promoting epithelial-mesenchymal transition.

The expression of TJP1 and OCLN further decreased after $6 \mathrm{~h}$ of A2E treatment $\left(\log _{2} \mathrm{FC}<-1\right)$ as well as there being a higher abundance of CAMSAP3 and KIFC3, if compared to the previous time point. In addition, adherens junction formation should be enhanced by down-expression of BMP6 and $R D X$, clustered in the "negative regulation of adherens junction organization" annotation term of the Gene Ontology database. Moreover, angiogenic markers such as CCN1 and VEGFA were up-regulated in H-RPE cells $6 \mathrm{~h}$ after treatment, when compared to untreated ones, suggesting that continuous exposure to the blue light can promote neo-vessel formation. This finding is further supported by the increased expression of FZD4 and LRP5, involved in the norrin signal pathway that contributes to retinal vasculature development.

\subsection{A2E Treatment Impairs Expression of AHR and ROM1}

Among 363 genes provided to the ToppGene tool as "Test gene set", 57 were prioritized according to functional annotations and protein interaction networks related to angiogenesis (Table S6). Eight of 
these genes are known to cause different RP phenotypes (Table 3). Surprisingly, only two of these, $A H R$ and ROM1, showed different expression values in A2E- treated H-RPE cells, when compared to untreated ones. In detail, under stress condition, $A H R$ was down-expressed while ROM1 up-regulated.

Table 3. RP causative genes differentially expressed in A2E-treated H-RPE cells. For each gene, the HUGO Gene Nomenclature Committee ID is indicated. The table also reports the RP phenotype linked to each locus, the role of the encoded protein in angiogenesis, and the expression values (as $\log _{2}$ FC) observed for each gene 3 and $6 \mathrm{~h}$ after A2E treatment. Not significant: gene expression change is not statistically significant. Not determined: no expression value detected by the analysis.

\begin{tabular}{|c|c|c|c|c|}
\hline $\begin{array}{c}\text { Locus } \\
\text { (HGCN ID) }\end{array}$ & RP Phenotype & Angiogenesis & $\begin{array}{l}\log _{2} \text { FC } 3 \\
\text { h_vs._0 h }\end{array}$ & $\begin{array}{l}\log _{2} \text { FC } 6 \\
\text { h_vs._0 h }\end{array}$ \\
\hline $\begin{array}{l}\text { AHR } \\
(348)\end{array}$ & recessive & $\begin{array}{c}\text { If depleted, } \\
\text { enhances retinal angiogenesis [37] }\end{array}$ & -0.78173956 & -1.52949254 \\
\hline $\begin{array}{l}\text { PROM1 } \\
\text { (9454) }\end{array}$ & $\begin{array}{l}\text { recessive with macular } \\
\text { degeneration }\end{array}$ & $\begin{array}{c}\text { Expressed on EPCS; } \\
\text { promotes neovascularization [38] }\end{array}$ & \multicolumn{2}{|c|}{ not significant } \\
\hline $\begin{array}{l}\text { MERTK } \\
(7027)\end{array}$ & recessive & $\begin{array}{l}\text { Promotes EC survival } \\
\text { by inhibiting apoptosis [39] }\end{array}$ & \multicolumn{2}{|c|}{ not significant } \\
\hline $\begin{array}{l}\text { RPE65 } \\
(10294)\end{array}$ & recessive & $\begin{array}{l}\text { Overexpressed in RPE cells } \\
\text { surrounding CNV [40] }\end{array}$ & \multicolumn{2}{|c|}{ not determined } \\
\hline $\begin{array}{l}\text { RHO } \\
(10012)\end{array}$ & $\begin{array}{l}\text { - dominant; } \\
\text { - recessive }\end{array}$ & $\begin{array}{l}\text { If mutated, leads to retinal vessels } \\
\text { atrophy following light exposure [41] }\end{array}$ & \multicolumn{2}{|c|}{ not significant } \\
\hline $\begin{array}{l}\text { NR2E3 } \\
(7974)\end{array}$ & $\begin{array}{l}\text { - recessive in Portuguese } \\
\text { Crypto Jews; } \\
\text { - dominant }\end{array}$ & $\begin{array}{l}\text { Regulates retinal neovascularization } \\
\text { by targeting FLT1 [42] }\end{array}$ & \multicolumn{2}{|c|}{ not significant } \\
\hline $\begin{array}{l}\text { SEMA4A } \\
(10729)\end{array}$ & dominant & $\begin{array}{l}\text { In ECs, suppresses VEGF-mediated } \\
\text { EC migration and proliferation by } \\
\text { binding Plexin-D1 [43] }\end{array}$ & \multicolumn{2}{|c|}{ not significant } \\
\hline $\begin{array}{l}\text { ROM1 } \\
(10254)\end{array}$ & dominant & $\begin{array}{l}\text { GO Biological process: } \\
\text { retina vasculature development in } \\
\text { camera-type eye (GO:0061298) }\end{array}$ & 1.256611685 & 1.123121917 \\
\hline $\begin{array}{l}\text { PANK2 } \\
(15894)\end{array}$ & $\begin{array}{c}\text { recessive HARP } \\
\text { (hypoprebetalipoproteinemia, } \\
\text { acanthocytosis, retinitis } \\
\text { pigmentosa, and palladial } \\
\text { degeneration) }\end{array}$ & $\begin{array}{l}\text { Required for normal development of } \\
\text { angiogenetic properties in ECs [44] }\end{array}$ & \multicolumn{2}{|c|}{ not significant } \\
\hline
\end{tabular}

\subsection{Quantitative RT-PCR Data Validation}

Quantitative RT-PCR confirmed the expression values observed by RNA sequencing. The same genes were considered for both time points and data are shown in Figure $4 \mathrm{a}$ as the average of the three replicates. Positive correlation indexes (3 h_vs._0 h, r: 0.99739771625149; 6 h_vs._0 h, r: 0.99952653060046$)$ were obtained by the ratio between $\log _{2}$ FC observed by RNAseq and qRT-PCR values (Figure $4 b, c)$. 

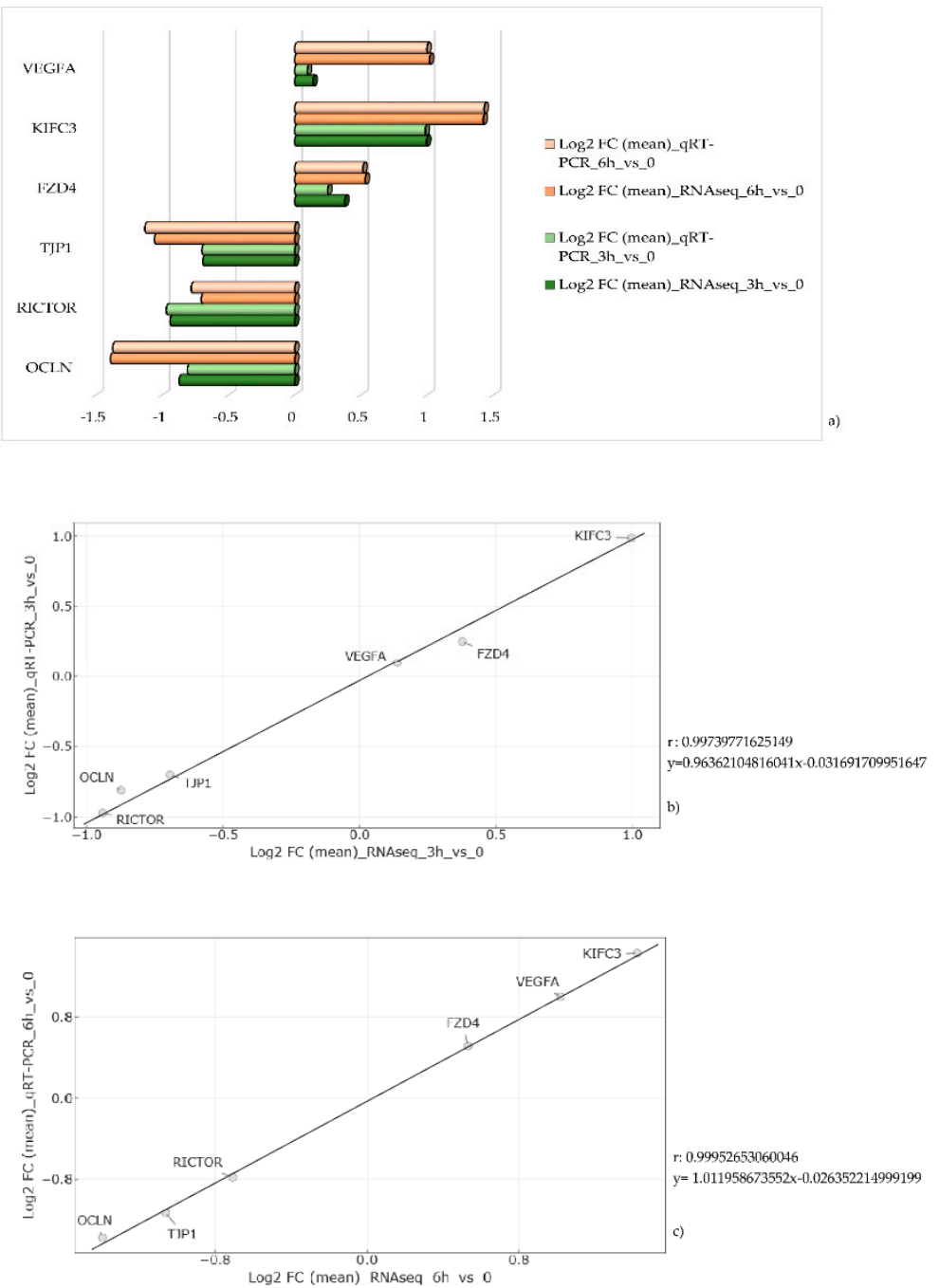

Figure 4. Real-time PCR results and correlation analysis. (a) The bar charts show a comparison between expression values (as $\log _{2}$ fold change (FC)) observed by qRT-PCR and RNA sequencing. Represented values are the average of the three replicates. (b,c) Correlation analysis between $\log _{2}$ FC observed values by RNAseq ( $x$-axis) and qRT-PCR ( $y$-axis) at the first (b) and at the second (c) time point.

\section{Discussion}

The eye is continuously exposed to both natural and artificial light and this was shown to increase ROS levels within the retina. In particular, RPE and photoreceptors are extremely sensitive to oxidative damage as visual pigments, proteins and lipids are targets of peroxidation reactions. Moreover, lasting ROS exposure can trigger an inflammation cascade that results in apoptotic photoreceptor death and vision loss [45]. For this reason, oxidative stress is considered one of the main causes of AMD that usually develops in adulthood. Oxidative damage was shown to be further induced by A2E treatment and light exposure [46]. However, impairment of ROS homeostasis due to genetic mutations can lead to the onset of hereditary retinal dystrophies and, among these, RP [47]. Occasionally, RP is accompanied by a vascular event known as choroidal neovascularization (CNV). It usually onsets late, probably due to an imbalance between pro-angiogenetic and anti-angiogenetic factors. However, the reason why $\mathrm{CNV}$ occurs is not yet clear. With expression analysis, we investigated the role of the endogenous adduct $\mathrm{A} 2 \mathrm{E}$ in stimulating the expression of genes involved in angiogenesis regulation. Our results showed that blue light damage occurring following A2E exposure can enhance expression of positive regulators of angiogenesis in RPE cells. RPE takes part in the formation of Bruch's membrane that separates photoreceptors from the choriocapillaris. As previously reported, A2E treatment and light 
exposure increased RPE early response against oxidative damage [48]. In contrast, expression increase of genes involved in angiogenesis is not an early event and occurs very slowly, in a time-dependent manner. This supports the evidence that neovascularization happens as a complication of RP. In detail, the first events of BRB barrier damage are indicated by the dysregulation of genes involved in cell junction maintenance and in ECM remodeling (Figure 5). (The percentages and $p$ values in Figure 5 must be converted into the UK/US system, i.e., 24,18 to 24.18 and $p=0,034$ to $p=0.034$ ).

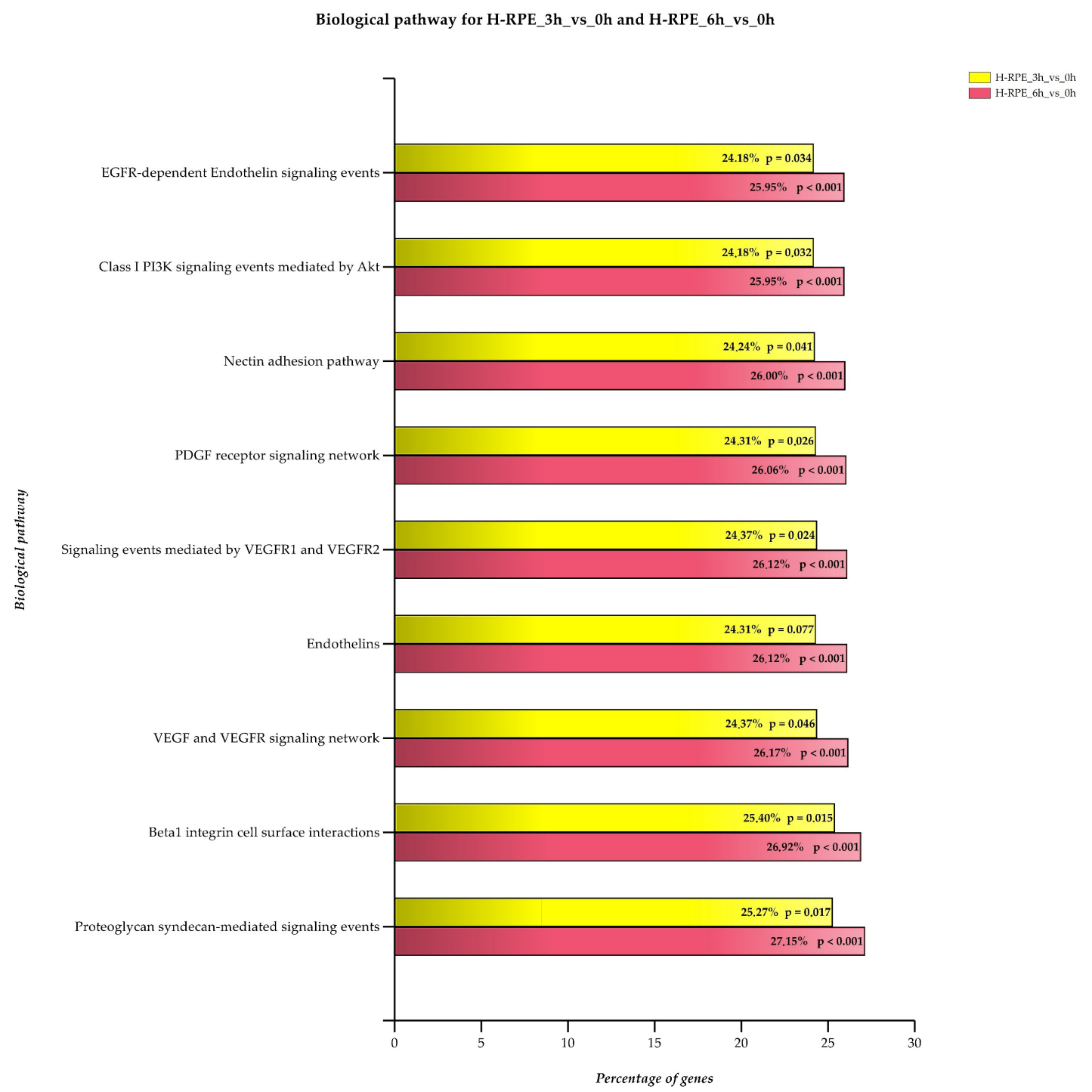

Figure 5. Enriched genes in biological pathways related to angiogenesis. Each biological pathway is considered both 3 and $6 \mathrm{~h}$ after A2E treatment. Enrichment percentage and the Bonferroni-adjusted $p$-value are reported.

A2E-treated cells showed dysregulated expression of genes clustered within nectin, focal adhesion kinase, E-cadherin and $\mathrm{N}$-cadherin adhesion pathways. Our results deal with those recently reported by Ibrahim et al. [49]. The authors observed the disruption of the RPE barrier due to increased MMP2 metalloproteinase activity, following high BMP4 concentration. BMP4 and MMP2 were upregulated also in our samples. The high expression level of $B M P 4$ has been shown to stimulate VEGFA production [50]. Moreover, A2E induced the disruption of tight junctions, as demonstrated by the down-expression of TJP1, OCLN and ROCK1 in treated RPE cells, when compared to untreated ones. Together with cell junctions, ECM also suffered blue light-induced stress, as shown by enrichment fold of the pathways related to $\beta$-integrin and proteoglycan signaling. Extracellular matrix remodeling 
in RP was linked to the increased MMP9 activity [51], while a protective role was established for its inhibitor TIMP1 [52]. TIMP1 expression increased in H-RPE cells after A2E supplementation, and this can be considered an attempt of protection against the oxidative substance. Although ECM remodeling signaling was observed early, expression of angiogenic markers significantly changed $6 \mathrm{~h}$ after the treatment, when endothelin, VEGF and PDGFB pathways were highly enriched. A2E treatment was shown to induce oxidative damage [46]. Under oxidative conditions, angiogenesis is enhanced due to a hypoxic condition by the activation of the PI3K/Akt cascade [53]. Despite the PI3K/Akt pathway perturbation not being described in RP, our hypothesis is that it can contribute to CNV development in patients with impaired oxidative stress defense mechanisms [54]. Moreover, the non-sudden overexpression of pro-angiogenic markers following A2E treatment can explain the reason why CNV emerges late in patients. Our results are consistent with a previous report by Vila et al., suggesting that blue light can induce vasculature remodeling in RPE cells [55,56].

Finally, we focused on RP causative genes that were dysregulated in H-RPE cells treated with $\mathrm{A} 2 \mathrm{E}$ and that play a role in angiogenesis regulation. In this context, prioritization analysis highlighted $A H R$ and ROM1. AHR encodes for the aryl hydrocarbon receptor, a transcription factor that inhibits transcription of pro-angiogenic genes. Oxidative stress reduced $A H R$ expression leading to endothelial cell proliferation [57]. Moreover, in endothelial barriers, AHR was shown to contribute to the maintenance of barrier properties by mediating cytochrome CYP1 expression, in response to xenobiotics [58]. Taken together, these data suggest that RP patients carrying AHR loss of function mutations might have an augmented risk of developing $C N V$, as they are pro-angiogenetic genes which are no longer inhibited. Furthermore, $A H R$ loss of function cannot preserve barrier integrity from continuous exposure to the cytotoxic effect of endogenous A2E.

In contrast, oxidative stress increased ROM1 expression. It encodes for a photoreceptor that is still poorly characterized. However, heterozygous ROM1 mutant mouse models showed narrowed retinal vasculature [59]. According to prioritization results, among all RP causative genes, here we propose that $A H R$ and ROM1 might preferably promote $\mathrm{CNV}$, since they are involved in the regulation of the angiogenic process. Knowledge of the mechanisms by which these genes can impair normal vasculature remodeling needs to be elucidated. Therefore, these are preliminary results that require further investigation to establish if $A H R$ and ROM1 mutations in RP patients can act as CNV-promoting factors.

\section{Conclusions}

Retinitis pigmentosa is a large heterogenous group of inherited retinal dystrophies. To date, more than 300 genes have been linked to RP development. Although oxidative stress is commonly observed in RP patients, not all patients have a better prognosis if treated with antioxidants. Likewise, only a few RP patients develop vascular phenotypes, such as CNV. Causes that lead to CNV have not yet been elucidated. Therefore, here we propose a model of oxidative stress induced by A2E treatment and blue light exposure, on human RPE cells. Our results demonstrate that the expression of pro-angiogenic genes increases in a time-dependent manner, after treatment. ECM remodeling and cell junction impairment are key events that can contribute to increasing permeability and loss of properties of the blood-retinal barrier. Moreover, two RP causative genes, $A H R$ and ROM1, can potentially promote $\mathrm{CNV}$ onset in RP patients.

Supplementary Materials: The following are available online at http://www.mdpi.com/2076-3921/9/11/ 1154/s1. Table S1: Differentially expressed genes; Table S2: FunRich_Report_H-RPE_3 h_vs._0 h; Table S3: FunRich_Report_H-RPE_6 h_vs._0 h; Table S4: FunRich_Report_H-RPE_6 h_vs._3 h; Table S5: FunRich_Report_DEGs_Angiogenesis; Table S6: ToppGene_Results.

Author Contributions: Conceptualization, C.S.; methodology, C.S. and L.D.; validation, S.Z.S. and S.A.; formal analysis, E.T.B.; data curation, C.S. and R.D.; writing-original draft preparation, C.S.; writing-review and editing, L.D., R.D. and A.S.; supervision, R.D.; project administration, A.S. All authors have read and agreed to the published version of the manuscript.

Funding: This research received no external funding. 
Conflicts of Interest: The authors declare no conflict of interest.

Data Deposition: According to the journal guidelines, RNA-Seq raw data were deposited in NCBI's Sequence Read Archive (SRA) and assigned to the project identifier PRJNA622997.

\section{References}

1. Fuhrmann, S.; Zou, C.; Levine, E.M. Retinal pigment epithelium development, plasticity, and tissue homeostasis. Exp. Eye Res. 2014, 123, 141-150. [CrossRef]

2. Muniz, A.; Betts, B.S.; Trevino, A.R.; Buddavarapu, K.; Roman, R.; Ma, J.X.; Tsin, A.T. Evidence for two retinoid cycles in the cone-dominated chicken eye. Biochemistry 2009, 48, 6854-6863. [CrossRef]

3. Fields, M.A.; Del Priore, L.V.; Adelman, R.A.; Rizzolo, L.J. Interactions of the choroid, Bruch's membrane, retinal pigment epithelium, and neurosensory retina collaborate to form the outer blood-retinal-barrier. Prog. Retin. Eye Res. 2020, 76, 100803. [CrossRef] [PubMed]

4. Hellinen, L.; Sato, K.; Reinisalo, M.; Kidron, H.; Rilla, K.; Tachikawa, M.; Uchida, Y.; Terasaki, T.; Urtti, A. Quantitative Protein Expression in the Human Retinal Pigment Epithelium: Comparison Between Apical and Basolateral Plasma Membranes with Emphasis on Transporters. Investig. Ophthalmol. Vis. Sci. 2019, 60, 5022-5034. [CrossRef] [PubMed]

5. Reichhart, N.; Strauss, O. Ion channels and transporters of the retinal pigment epithelium. Exp. Eye Res. 2014, 126, 27-37. [CrossRef]

6. Zhang, H.; Wong, C.L.; Shan, S.W.; Li, K.K.; Cheng, A.K.; Lee, K.L.; Ge, J.; To, C.H.; Do, C.W. Characterisation of $\mathrm{Cl}^{-}$transporter and channels in experimentally induced myopic chick eyes. Clin. Exp. Optom. 2011, 94, 528-535. [CrossRef] [PubMed]

7. He, Y.; Leung, K.W.; Ren, Y.; Pei, J.; Ge, J.; Tombran-Tink, J. PEDF improves mitochondrial function in RPE cells during oxidative stress. Investig. Ophthalmol. Vis. Sci. 2014, 55, 6742-6755. [CrossRef]

8. Hernández, C.; Simó-Servat, O.; Simó, R. Somatostatin and diabetic retinopathy: Current concepts and new therapeutic perspectives. Endocrine 2014, 46, 209-214. [CrossRef]

9. Samson, F.P.; He, W.; Sripathi, S.R.; Patrick, A.T.; Madu, J.; Chung, H.; Frost, M.C.; Jee, D.; Gutsaeva, D.R.; Jahng, W.J. Dual Switch Mechanism of Erythropoietin as an Antiapoptotic and Pro-Angiogenic Determinant in the Retina. ACS Omega 2020, 5, 21113-21126. [CrossRef]

10. Farnoodian, M.; Kinter, J.B.; Yadranji Aghdam, S.; Zaitoun, I.; Sorenson, C.M.; Sheibani, N. Expression of pigment epithelium-derived factor and thrombospondin-1 regulate proliferation and migration of retinal pigment epithelial cells. Physiol. Rep. 2015, 3, e12266. [CrossRef]

11. Zadeh, J.K.; Zhutdieva, M.B.; Laspas, P.; Yuksel, C.; Musayeva, A.; Pfeiffer, N.; Brochhausen, C.; Oelze, M.; Daiber, A.; Xia, N.; et al. Apolipoprotein E Deficiency Causes Endothelial Dysfunction in the Mouse Retina. Oxid. Med. Cell Longev. 2019, 2019, 5181429. [CrossRef] [PubMed]

12. De Kozak, Y.; Cotinet, A.; Goureau, O.; Hicks, D.; Thillaye-Goldenberg, B. Tumor necrosis factor and nitric oxide production by resident retinal glial cells from rats presenting hereditary retinal degeneration. Ocul. Immunol. Inflamm. 1997, 5, 85-94. [CrossRef] [PubMed]

13. Tisi, A.; Parete, G.; Flati, V.; Maccarone, R. Up-regulation of pro-angiogenic pathways and induction of neovascularization by an acute retinal light damage. Sci. Rep. 2020, 10, 6376. [CrossRef] [PubMed]

14. Dong, Y.; Cai, X.; Wu, Y.; Liu, Y.; Deng, L.; Chen, H. Insights from Genetic Model Systems of Retinal Degeneration: Role of Epsins in Retinal Angiogenesis and VEGFR2 Signaling. J. Nat. Sci. 2017, 3, e281.

15. Shen, C.; Li, Y.; Wang, Q.; Chen, Y.N.; Li, W.; Wei, W.B. Choroidal vascular changes in retinitis pigmentosa patients detected by optical coherence tomography angiography. BMC Ophthalmol. 2020, 20, 384. [CrossRef]

16. Garafalo, A.V.; Cideciyan, A.V.; Héon, E.; Sheplock, R.; Pearson, A.; WeiYang Yu, C.; Sumaroka, A.; Aguirre, G.D.; Jacobson, S.G. Progress in treating inherited retinal diseases: Early subretinal gene therapy clinical trials and candidates for future initiatives. Prog. Retin. Eye Res. 2020, 77, 100827. [CrossRef]

17. Strobbe, E.; Cellini, M.; Fresina, M.; Campos, E.C. ET-1 Plasma Levels, Aqueous Flare, and Choroidal Thickness in Patients with Retinitis Pigmentosa. J. Ophthalmol. 2015, 2015, 292615. [CrossRef]

18. Narayan, S.; Prasanna, G.; Tchedre, K.; Krishnamoorthy, R.; Yorio, T. Thrombin-induced endothelin-1 synthesis and secretion in retinal pigment epithelial cells is rho kinase dependent. J. Ocul. Pharmacol. Ther. 2010, 26, 389-397. [CrossRef] 
19. Li, Z.Y.; Possin, D.E.; Milam, A.H. Histopathology of bone spicule pigmentation in retinitis pigmentosa. Ophthalmology 1995, 102, 805-816. [CrossRef]

20. Farnoodian, M.; Halbach, C.; Slinger, C.; Pattnaik, B.R.; Sorenson, C.M.; Sheibani, N. High glucose promotes the migration of retinal pigment epithelial cells through increased oxidative stress and PEDF expression. Am. J. Physiol. Cell Physiol. 2016, 311, C418-C436. [CrossRef]

21. Marano, F.; Deutman, A.F.; Leys, A.; Aandekerk, A.L. Hereditary retinal dystrophies and choroidal neovascularization. Graefes Arch. Clin. Exp. Ophthalmol. 2000, 238, 760-764. [CrossRef] [PubMed]

22. Malik, A.; Sood, S.; Narang, S. Successful treatment of choroidal neovascular membrane in retinitis pigmentosa with intravitreal bevacizumab. Int. Ophthalmol. 2010, 30, 425-428. [CrossRef] [PubMed]

23. Campochiaro, P.A.; Mir, T.A. The mechanism of cone cell death in Retinitis Pigmentosa. Prog. Retin. Eye Res. 2018, 62, 24-37. [CrossRef] [PubMed]

24. Okonechnikov, K.; Conesa, A.; García-Alcalde, F. Qualimap 2: Advanced multi-sample quality control for high-throughput sequencing data. Bioinformatics 2016, 32, 292-294. [CrossRef]

25. Bolger, A.M.; Lohse, M.; Usadel, B. Trimmomatic: A flexible trimmer for Illumina sequence data. Bioinformatics 2014, 30, 2114-2120. [CrossRef]

26. Li, B.; Ruotti, V.; Stewart, R.M.; Thomson, J.A.; Dewey, C.N. RNA-Seq gene expression estimation with read mapping uncertainty. Bioinformatics 2010, 26, 493-500. [CrossRef]

27. Ritchie, M.E.; Phipson, B.; Wu, D.; Hu, Y.; Law, C.W.; Shi, W.; Smyth, G.K. limma powers differential expression analyses for RNA-sequencing and microarray studies. Nucleic Acids Res. 2015, 43, e47. [CrossRef]

28. Mitchell, A.L.; Attwood, T.K.; Babbitt, P.C.; Blum, M.; Bork, P.; Bridge, A.; Brown, S.D.; Chang, H.Y.; El-Gebali, S.; Fraser, M.I.; et al. InterPro in 2019: Improving Coverage, Classification and Access to Protein Sequence Annotations. Nucleic Acids Res. 2019, 47, D351-D360. [CrossRef]

29. Jassal, B.; Matthews, L.; Viteri, G.; Gong, C.; Lorente, P.; Fabregat, A.; Sidiropoulos, K.; Cook, J.; Gillespie, M.; Haw, R.; et al. The Reactome Pathway Knowledgebase. Nucleic Acids Res. 2020, 48, D498-D503. [CrossRef]

30. Uhlen, M.; Zhang, C.; Lee, S.; Sjöstedt, E.; Fagerberg, L.; Bidkhori, G.; Benfeitas, R.; Arif, M.; Liu, Z.; Edfors, F.; et al. A Pathology Atlas of the Human Cancer Transcriptome. Science 2017, 357, eaan2507. [CrossRef]

31. The UniProt Consortium. UniProt: The Universal Protein Knowledgebase. Nucleic Acids Res. 2018, 46, 2699. [CrossRef] [PubMed]

32. Orchard, S.; Ammari, M.; Aranda, B.; Breuza, L.; Briganti, L.; Broackes-Carter, F.; Campbell, N.H.; Chavali, G.; Chen, C.; del-Toro, N.; et al. The MIntAct project-IntAct as a Common Curation Platform for 11 Molecular Interaction Databases. Nucleic Acids Res. 2014, 42, D358-D563. [CrossRef] [PubMed]

33. Aken, B.L.; Ayling, S.; Barrell, D.; Clarke, L.; Curwen, V.; Fairley, S.; Banet, J.F.; Billis, K.; García Girón, C.; Hourlier, T.; et al. The Ensembl Gene Annotation System. Database 2016, 2016, baw093. [CrossRef] [PubMed]

34. Wain, H.M.; Bruford, E.A.; Lovering, R.C.; Lush, M.J.; Wright, M.W.; Povey, S. Guidelines for Human Gene Nomenclature. Genomics 2002, 79, 464-470. [CrossRef]

35. Pathan, M.; Keerthikumar, S.; Chisanga, D.; Alessandro, R.; Ang, C.S.; Askenase, P.; Batagov, A.O.; Benito-Martin, A.; Camussi, G.; Clayton, A.; et al. A novel community driven software for functional enrichment analysis of extracellular vesicles data. J. Extracell. Vesicles 2017, 6, 1321455. [CrossRef]

36. Chen, J.; Bardes, E.E.; Aronow, B.J.; Jegga, A.G. ToppGene Suite for gene list enrichment analysis and candidate gene prioritization. Nucleic Acids Res. 2009, 37, W305-W311. [CrossRef]

37. Choudhary, M.; Kazmin, D.; Hu, P.; Thomas, R.S.; McDonnell, D.P.; Malek, G. Aryl hydrocarbon receptor knock-out exacerbates choroidal neovascularization via multiple pathogenic pathways. J. Pathol. 2015, 235, 101-112. [CrossRef]

38. Herrmann, M.; Binder, A.; Menzel, U.; Zeiter, S.; Alini, M.; Verrier, S. CD34/CD133 enriched bone marrow progenitor cells promote neovascularization of tissue engineered constructs in vivo. Stem Cell Res. 2014, 13, 465-477. [CrossRef]

39. Novitskiy, S.V.; Zaynagetdinov, R.; Vasiukov, G.; Gutor, S.; Han, W.; Serezani, A.; Matafonov, A.; Gleaves, L.A.; Sherrill, T.P.; Polosukhin, V.V.; et al. Gas6/MerTK signaling is negatively regulated by NF-kB and supports lung carcinogenesis. Oncotarget 2019, 10, 7031-7042. [CrossRef] 
40. Liu, S.; Biesemeier, A.K.; Tschulakow, A.V.; Thakkar, H.V.; Julien-Schraermeyer, S.; Schraermeyer, U. A new rat model of treatment-naive quiescent choroidal neovascularization induced by human VEGF165 overexpression. Biol. Open. 2020, 9, bio048736. [CrossRef]

41. Massengill, M.T.; Young, B.; Patel, D.; Jafri, F.; Sabogal, E.; Ash, N.; Li, H.; Ildefonso, C.J.; Lewin, A.S. Clinically Relevant Outcome Measures for the I307N Rhodopsin Mouse: A Model of Inducible Autosomal Dominant Retinitis Pigmentosa. Investig. Ophthalmol. Vis. Sci. 2018, 59, 5417-5430. [CrossRef] [PubMed]

42. Owen, L.A.; Morrison, M.A.; Ahn, J.; Woo, S.J.; Sato, H.; Robinson, R.; Morgan, D.J.; Zacharaki, F.; Simeonova, M.; Uehara, H.; et al. FLT1 genetic variation predisposes to neovascular AMD in ethnically diverse populations and alters systemic FLT1 expression. Investig. Ophthalmol. Vis. Sci. 2014, 55, 3543-3554. [CrossRef] [PubMed]

43. Ito, D.; Kumanogoh, A. The role of Sema4A in angiogenesis, immune responses, carcinogenesis, and retinal systems. Cell Adhes. Migr. 2016, 10, 692-699. [CrossRef] [PubMed]

44. Pagani, F.; Trivedi, A.; Khatri, D.; Zizioli, D.; Garrafa, E.; Mitola, S.; Finazzi, D. Silencing of pantothenate kinase 2 reduces endothelial cell angiogenesis. Mol. Med. Rep. 2018, 18, 4739-4746. [CrossRef] [PubMed]

45. Subramanian, P.; Becerra, S.P. Role of the PNPLA2 Gene in the Regulation of Oxidative Stress Damage of RPE. Adv. Exp. Med. Biol. 2019, 1185, 377-382.

46. Marie, M.; Bigot, K.; Angebault, C.; Barrau, C.; Gondouin, P.; Pagan, D.; Fouquet, S.; Villette, T.; Sahel, J.A.; Lenaers, G.; et al. Light action spectrum on oxidative stress and mitochondrial damage in A2E-loaded retinal pigment epithelium cells. Cell Death Dis. 2018, 9, 287. [CrossRef]

47. Nakagami, Y.; Hatano, E.; Inoue, T.; Yoshida, K.; Kondo, M.; Terasaki, H. Cytoprotective Effects of a Novel Nrf2 Activator, RS9, in Rhodopsin Pro347Leu Rabbits. Curr. Eye Res. 2016, 41, 1123-1126. [CrossRef]

48. Donato, L.; D'Angelo, R.; Alibrandi, S.; Rinaldi, C.; Sidoti, A.; Scimone, C. Effects of A2E-Induced Oxidative Stress on Retinal Epithelial Cells: New Insights on Differential Gene Response and Retinal Dystrophies. Antioxidants 2020, 9, 307. [CrossRef]

49. Ibrahim, A.S.; Hussein, K.; Wang, F.; Wan, M.; Saad, N.; Essa, M.; Kim, I.; Shakoor, A.; Owen, L.A.; DeAngelis, M.M.; et al. Bone Morphogenetic Protein (BMP)4 But Not BMP2 Disrupts the Barrier Integrity of Retinal Pigment Epithelia and Induces Their Migration: A Potential Role in Neovascular Age-Related Macular Degeneration. J. Clin. Med. 2020, 9, 2293. [CrossRef]

50. Vogt, R.R.; Unda, R.; Yeh, L.C.; Vidro, E.K.; Lee, J.C.; Tsin, A.T. Bone morphogenetic protein-4 enhances vascular endothelial growth factor secretion by human retinal pigment epithelial cells. J. Cell. Biochem. 2006, 98, 1196-1202. [CrossRef]

51. Shin, J.A.; Kim, H.S.; Vargas, A.; Yu, W.Q.; Eom, Y.S.; Craft, C.M.; Lee, E.J. Inhibition of Matrix Metalloproteinase 9 Enhances Rod Survival in the S334ter-line3 Retinitis Pigmentosa Model. PLoS ONE 2016, 11, e0167102. [CrossRef] [PubMed]

52. Kim, H.S.; Vargas, A.; Eom, Y.S.; Li, J.; Yamamoto, K.L.; Craft, C.; Lee, E.J. Tissue inhibitor of metalloproteinases 1 enhances rod survival in the rd1 mouse retina. PLoS ONE 2018, 13, e0197322. [CrossRef] [PubMed]

53. Zhu, M.; Liu, X.; Wang, S.; Miao, J.; Wu, L.; Yang, X.; Wang, Y.; Kang, L.; Li, W.; Cui, C.; et al. PKR promotes choroidal neovascularization via upregulating the PI3K/Akt signaling pathway in VEGF expression. Mol. Vis. 2016, 22, 1361-1374. [PubMed]

54. Domènech, E.B.; Marfany, G. The Relevance of Oxidative Stress in the Pathogenesis and Therapy of Retinal Dystrophies. Antioxidants 2020, 9, 347. [CrossRef]

55. Vila, N.; Siblini, A.; Esposito, E.; Bravo-Filho, V.; Zoroquiain, P.; Aldrees, S.; Logan, P.; Arias, L.; Burnier, M.N. Blue-light filtering alters angiogenic signaling in human retinal pigmented epithelial cells culture model. BMC Ophthalmol. 2017, 17, 198. [CrossRef]

56. Zhou, J.; Sparrow, J.R. Light filtering in a retinal pigment epithelial cell culture model. Optom. Vis. Sci. 2011, 88, 759-765. [CrossRef]

57. Li, Y.; Zhou, C.; Lei, W.; Wang, K.; Zheng, J. Roles of Aryl Hydrocarbon Receptor in Endothelial Angiogenic Responses. Biol. Reprod. 2020, 103, 927-937. [CrossRef] 
58. Ziegler, N.; Awwad, K.; Fisslthaler, B.; Reis, M.; Devraj, K.; Corada, M.; Minardi, S.P.; Dejana, E.; Plate, K.H.; Fleming, I.; et al. $\beta$-Catenin Is Required for Endothelial Cyp1b1 Regulation Influencing Metabolic Barrier Function. J. Neurosci. 2016, 36, 8921-8935. [CrossRef]

59. Sato, H.; Suzuki, T.; Ikeda, K.; Masuya, H.; Sezutsu, H.; Kaneda, H.; Kobayashi, K.; Miura, I.; Kurihara, Y.; Yokokura, S.; et al. A monogenic dominant mutation in Rom1 generated by N-ethyl-N-nitrosourea mutagenesis causes retinal degeneration in mice. Mol. Vis. 2010, 16, 378-391.

Publisher's Note: MDPI stays neutral with regard to jurisdictional claims in published maps and institutional affiliations.

(C) 2020 by the authors. Licensee MDPI, Basel, Switzerland. This article is an open access article distributed under the terms and conditions of the Creative Commons Attribution (CC BY) license (http://creativecommons.org/licenses/by/4.0/). 